\title{
EVALUASI TATA KELOLA TEKNOLOGI INFORMASI DI DINAS KOMUNIKASI DAN INFORMATIKA MENGGUNAKAN FRAMEWORK COBIT 5
}

\author{
Asnita Hanif ${ }^{1}$, M. Giatman ${ }^{2}$, Ahmaddul Hadi ${ }^{3}$ \\ ${ }^{1}$ Program Magister Chief Information Officer, Fakultas Teknik, Universitas Negeri Padang, \\ Padang, Indonesia \\ 2 Jurusan Teknik Sipil, Fakultas Teknik, Universitas Negeri Padang, Padang, Indonesia \\ ${ }^{3}$ Jurusan Teknik Elektronika, Fakultas Teknik, Universitas Negeri Padang, Padang, Indonesia \\ e-mail: asnitahanif7@gmail.com, giatmanm07@gmail.com, hadiahmaddul22@gmail.com
}

\begin{abstract}
Abstrak
Perkembangan teknologi dan informasi telah memberikan dampak terhadap organisasi, baik instansi swasta maupun pemerintahan, maka diperlukan evaluasi untuk memberikan saran dan masukan. Tujuan penelitian ini adalah untuk menganalisis keadaan tata kelola teknologi informasi di Dinas Komunikasi dan Informatika Kota Payakumbuh. Metode penelitian ini yakni deskriptif kualitatif, dengan subjek Dinas Komunikasi dan Informatika Kota Payakumbuh, dan objek penelitian ini adalah tingkat kapabilitas tata kelola teknologi dan informasi. Penelitian ini menggunakan framework COBIT 5 sebagai alat ukur model proses kapabilitas. Metode pengumpulan data yang digunakan adalah metode observasi dan studi literatur. Data yang telah diperoleh dianalisis menggunakan metode analisis statistik deskriptif kualitatif. Hasil pelenitian ini adalah proses DSS01 (Manage Operasional), DSS03 (Manage Problems) dan DSS05 (Manage Security Services) telah mencapai level 1 Performed Process karena atribut PA 1.1 mencapai kategori L. Simpulan penelitian ini adalah terdapat kelemahan dalam tata kelola dan manajemen teknologi dan informasi pada Dinas Komunikasi dan Informatika Kota Payakumbuh.
\end{abstract}

Kata kunci: Evaluasi, COBIT 5, Teknologi Informasi

\begin{abstract}
The development of technology and information has had an impact on organizations, both private and government agencies, so evaluation is needed to provide suggestions and input. The purpose of this study was to analyze the state of information technology governance in the Payakumbuh Information and Communication Office. This research method is descriptive qualitative, with the subject of the Department of Communication and Information of Payakumbuh City, and the object of this research is the capability level of technology and information governance. This study uses the COBIT 5 framework as a measurement tool for the capability process model. The data collection method used is the method of observation and literature study. The data that has been obtained were analyzed using qualitative descriptive statistical analysis methods. The results of this research are that the DSS01 (Manage Operational), DSS03 (Manage Problems) and DSS05 (Manage Security Services) processes have reached level 1 Performed Process because the PA 1.1 attribute reaches the $L$ category. The conclusion of this study is that there are weaknesses in governance and technology management and information on the Department of Communication and Information of the City of Payakumbuh.
\end{abstract}

Keywords: Evaluation, COBIT 5, IT

\section{PENDAHULUAN}

Teknologi informasi memiliki peranan yang sangat penting saat ini. Hampir semua aspek kegiatan bisnis sekarang didukung oleh sistem dan teknologi informasi baik secara langsung maupun tidak langsung. Keberadaan teknologi informasi itu sendiri juga sangat membantu dalam memudahkan segala urusan perorganisasian baik di sektor instansi 
swasta maupun pemerintahan. Manfaat yang sangat dirasakan dari teknologi informasi ini adalah tentang efisiensi dan efektifitas dari setiap rangkaian kegiatan organisasi tersebut, yang mana manfaat ini akan sulit didapat jika kegiatan organisasi masih dilakukan secara tradisional (Hariyani \& Sudrajat, 2017; Utomo et al., 2012).

Teknologi informasi pada bidang pemerintahan dibutuhkan untuk menciptakan proses penyelenggaraan pemerintahan yang baik (good governance). Ciri-ciri pemerintahan yang telah menerapkan proses good governance adalah memiliki pemerintahan yang transparan, akuntabel, efektif dan efisien (Najwa \& Susanto, 2018; Suradi \& Wiyanta, 2017). Dinas Komunikasi dan Informatika Kota Payakumbuh adalah salah satu organisasi perangkat daerah (OPD) yang mempunyai tugas pokok sebagai pembantu Walikota melaksanakan segala urusan pemerintahan daerah yang berkaitan dengan bidang komunikasi dan informatika, bidang persandian dan bidang statistik sesuai dengan visi dan misi dari daerah itu sendiri. Penelitian ini akan menggunakan framework COBIT 5 sebagai kerangka kerja dalam mengevaluasi tata kelola teknologi informasi yang ada di Dinas Komunikasi dan Informatika Kota Payakumbuh.

Beberapa alasan dipilihnya framework COBIT 5 adalah karena COBIT 5 sesuai dengan standar yang dibutuhkan dan kerangka kerja ini juga berguna secara langsung bagi perusahaan dan memungkinkan COBIT 5 dapat digunakan oleh perusahaan/instansi pemerintah sebagai kerangka kerja dalam mengelola tata kelola dan manajemen secara menyeluruh dan terintegrasi. COBIT 5 sangat lengkap menyediakan dasar untuk secara efektif mengintegrasikan kerangka kerja, standar, dan praktik lain yang telah digunakan yang mana standar tersebut menjangkau semua lingkup perusahaan/instansi tersebut (Damayanti \& Manuputty, 2019; Firdaus \& Suprapto, 2018).

Evaluasi adalah suatu rangkaian kegiatan dalam mengumpulkan informasi tentang babagai suatu proses yang terjadi, informasi yang telah dikumpulkan tersebut digunakan untuk menentukan pilihan dan saran untuk mengambil keputusan. Berhasil atau tidaknya dan ada atau tidak adanya manfaat dari sebuah program kebijakan dapat juga dilakukan sebuah proses yang namanya evaluasi. Evaluasi dapat diartikan juga sebagai proses memberikan nilai terhadap dampak dari suatu program, objek atau sebuah rangkaian proses dengan rangkaian dan persyaratan yang telah ditentukan sebelumnya (Fajarwati et al., 2018; Kurniawan, 2018).

COBIT 5 merupakan sebuah kerangka menyeluruh yang dapat membantu organisasi dalam mencapai tujuannya untuk tata kelola dan manajemen TI organisasi. Secara sederhana, COBIT 5 membantu perusahaan menciptakan nilai optimal dari TI dengan cara menjaga keseimbangan antara mendapatkan keuntungan dan mengoptimalkan tingkat risiko dan penggunaan sumber daya (Ismail \& Winarno, 2017; Mutiah, 2019).

Penelitian ini didukung oleh penelitian sebelumnya yang relevan, seperti: (1) penelitian yang dilaksanakan oleh (Kurniawan, 2018), yang mendapatkan hasil yaitu Dinas Kependudukan dan Catatan Sipil Kabupaten Bogor telah memiliki pola untuk mengelola proses terkait berdasarkan keberhasilan pengalaman yang berulang yang pernah dilakukan sebelumnya tetapi pola yang dilakukan belum berstandar. (2) penelitian yang dilaksanakan oleh (Fajarwati et al., 2018), yang mendapatkan hasil yaitu implementasi $\mathrm{TI}$ di Kantor Kecamatan Baturraden telah berjalan dan mencapai tujuannya, namun belum ada proses untuk memastikan keuntungan dalam proses pengiriman dan optimasi resiko yang ditetapkan, dan dicapai keluaran yang sesuai harapan. (3) penelitian yang dilaksanakan oleh (Rizki et al., 2016), yang mendapatkan hasil yaitu evaluasi pengukuran kualitas sistem, kualitas informasi dan kualitas layanan BI di PMRI berdasarkan tingkat kepentingan dan kinerja bisa disimpulkan bahwa untuk 
kualitas sistem kinerja yang rendah dan perlu mendapat prioritas utama untuk perbaikannya yaitu keandalan sistem BI, aksesibilitas, serta efisiensi. Sedangkan untuk peningkatan kualitas informasi dapat memperioritaskan atribut akurasi dan tepat waktu.

Berdasarkan beberapa penelitian yang relevan tersebut, adapun kebaruan penelitian ini adalah belum ada yang melaksanakan penelitian tentang evaluasi

\section{METODE}

Penelitian yang akan dilakukan ini adalah penelitian deskriptif kualitatif. Tujuan penelitian ini adalah untuk mengetahui fakta dan keadaan yang sebenarnya terjadi pada saat penelitian dilakukan sesuai dengan rumusan masalah dan identifikasi masalah yang telah dikemukakan sebelumnya. Subjek penelitian ini adalah Dinas Komunikasi dan Informatika Kota tata kelola teknologi informasi di dinas komunikasi dan informatika menggunakan framework cobit 5, khususnya pada pada organisasi pemerintahan. Tujuan penelitian ini untuk menganalisis keadaan tata kelola teknologi informasi di Dinas Komunikasi dan Informatika Kota Payakumbuh.

Payakumbuh, dan objek penelitian ini adalah tingkat kapabilitas tata kelola teknologi dan informasi.

Metode pengumpulan data yang digunakan adalah metode observasi dan studi literatur serta penelitian ini menggunakan framework COBIT 5 sebagai alat ukur model proses kapabilitas. Prinsip utama COBIT 5 dapat dilihat pada gambar 1 .

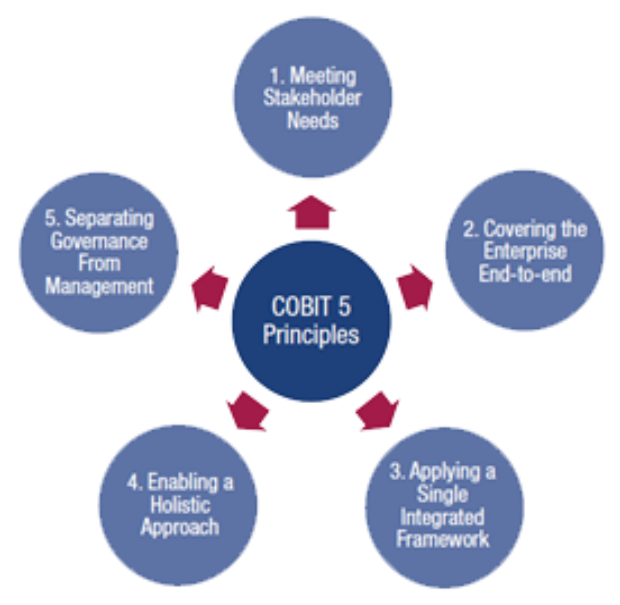

Gambar 1. Prinsip Utama COBIT 5

Domain DSS sesuai dengan kondisi di Diskominfo Kota Payakumbuh yaitu untuk mengevaluasi kondisi sistem informasi yang sudah ada dari sisi pengiriman, layanan, dan dukungan layanan TI. Diskominfo Kota Payakumbuh sudah menerapkan implementasi TI secara sebagian dari operasionalnya, sehingga evaluasi ini perlu dilakukan untuk mengukur efektifitas dan efisiensi operasional yang organisasi lakukan.

Kegiatan awal penelitian ini adalah meliputi proses observasi mengenai kondisi pemanfaatan TI di Dinas Komunikasi dan
Informatika Kota Payakumbuh kemudian mengidentifikasi permasalahan yang muncul. Langkah berikutnya adalah pengumpulan data profil organisasi terutama tujuan organisasi. Selanjutnya dilakukan pemetaan dari tujuan organisasi sehingga dapat ditentukan proses yang menjadi fokus kajian penelitian.

Setelah pengukuran berupa tingkat kapabilitas proses COBIT 5, data yang telah diperoleh dianalisis menggunakan metode analisis statistik deskriptif kualitatif. Dilaksanakan pemilihan prioritas dari proses yang akan dilakukan perbaikan dan 
pemilihan prioritas berupa rekomendasi dalam bentuk tindakan perbaikan bagi setiap proses COBIT terpilih.

\section{HASIL DAN PEMBAHASAN}

Dari hasil rekapitulasi masing-masing atribut kapabilitas maka dapat di gambarkan profil pencapaian tingkat kapabilitas dari masing-masing atribut perproses seperti yang ditunjukkan Gambar 2.

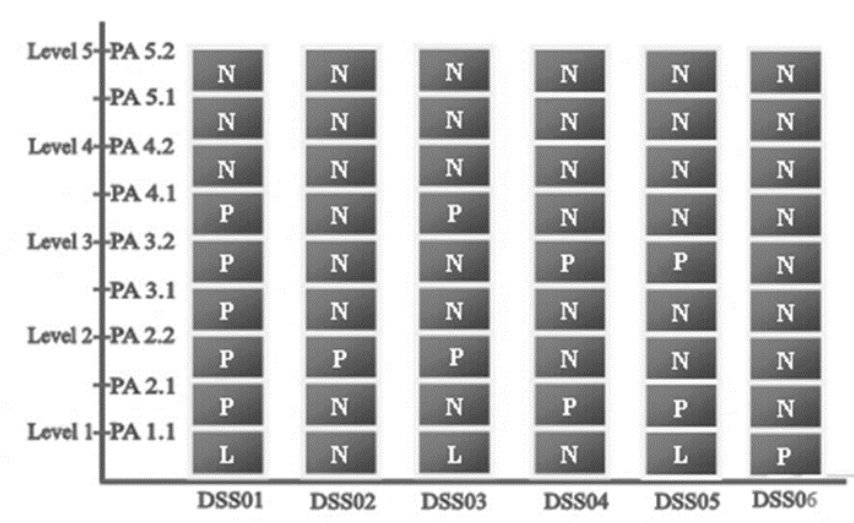

Gambar 2. Profil Level Kapabilitas Proses

Dari gambar 2 dapat dilihat bahwa proses DSS01 (Manage Operasional), DSS03 (Manage Problems) dan DSS05 (Manage Security Services) telah mencapai level 1 Performed Process karena atribut PA 1.1 mencapai kategori $L$. Hal ini berarti bahwa proses pengelolaan operasional telah diimplementasikan hal ini di tandai dengan telah dilaksanakannya praktekpraktek dasar dalam pengelolaan operasional, namun masih terdapat beberapa kelemahan dalam pengelolaan operasional seperti tidak terdokumentasinya dengan baik work produk dari praktekpraktek dasar yang telah dilaksanakan dan masih ada beberapa praktek dasar yang belum terlaksana dengan baik. Proses DSS02, DSS04 dan DSS06 gagal mencapai level 1 atau masih dikategorikan pada level 0 . Kapabilitas saat ini dengan yang diharapkan dapat dilihat pada tabel 1

Tabel 1. Kondisi Tingkat Kapabilitas saat ini dan yang diharapkan

\begin{tabular}{ccccc}
\hline \multirow{2}{*}{ No } & \multirow{2}{*}{ Proses TI } & \multicolumn{2}{c}{ Tingkat Kapabilitas (Level) } & \multirow{2}{*}{ Gap } \\
\cline { 3 - 5 } & & As-is & To-be & \\
\hline 1 & DSS01 & 1 & 2 & 1 \\
2 & DSS02 & 0 & 2 & 2 \\
3 & DSS03 & 1 & 2 & 1 \\
4 & DSS04 & 0 & 2 & 2 \\
5 & DSS05 & 1 & 2 & 1 \\
6 & DSS06 & 0 & 2 & 2 \\
\hline
\end{tabular}

Pada tabel satu proses DSS02, DSS04 dan DSS06 gagal mencapai level 1 atau masih dikategorikan pada level 0 . Hal ini disebabkan atribut PA 1.1 tidak mencapai kategori minimal L (largely achieved) karena untuk bisa dikatakan mencapai level 1 maka atribut PA 1.1 minimal pada kategori $L$. Untuk kesenjangan tingkat kapabilitas dapat dilihat pada gambar 3 . 


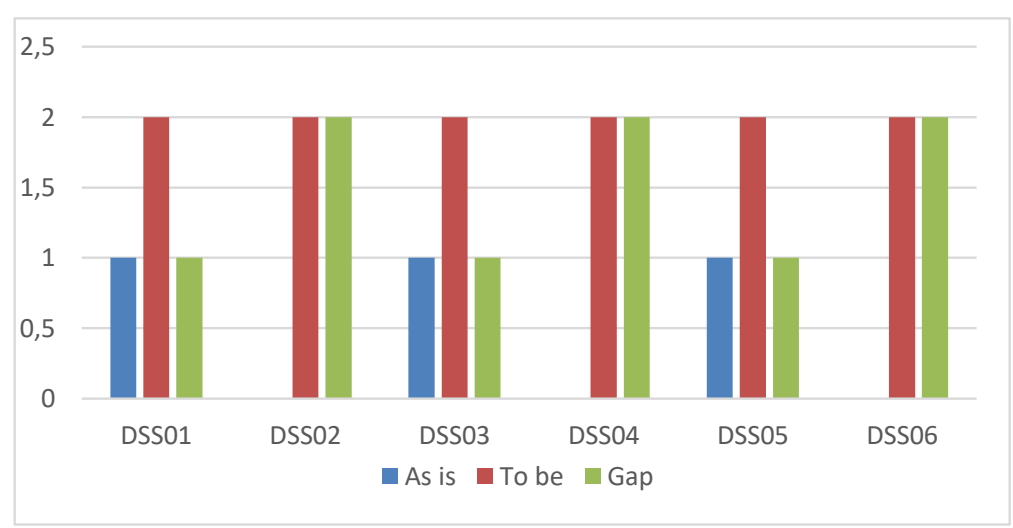

Gambar 3. Kesenjangan Tingkat Kapabillitas

Berdasarkan kondisi yang ada saat ini dan target yang diharapkan maka rata-rata selisih gap proses adalah dua. Dasar pertimbangan terjadinya pemilihan target yang hendak dicapai pada level 2 adalah penyesuaian terhadap tingkat kapabilitas yang telah mampu dicapai saat ini, untuk menghindari tingkat perbedaan yang terlalu jauh. Dari gambar 3 yang telah disajikan dalam bentuk grafik, dapat di simpulkan bahwa gap yang terjadi untuk masingmasing proses yaitu, pertama pada proses manage operasional (DSS01) atribut proses performance ditargetkan menjadi Full Achieved sedangkan saat ini masih bernilai Largely achieved. Atribut performance management ditargetkan menjadi Largely Achieved sedangkan saat ini masih Partially achieved dan atribut work product management ditargetkan largely achieved atau Full Achieved sedangkan saat ini masih Partially achieved.

Kedua pada proses mengelola permintaan layanan dan gangguan (DSS02) atribut proses performance ditargetkan menjadi Full Achieved sedangkan saat ini masih bernilai Not achieved. Atribut performance management ditargetkan menjadi Largely Achieved atau Full Achieved sedangkan saat ini masih Not achieved dan atribut work product management ditargetkan Largely Achieved atau Full Achieved sedangkan saat ini masih Partially achieved.

Ketiga pada proses manage problems (DSS03) atribut proses performance ditargetkan menjadi Full Achieved sedangkan saat ini masih bernilai Largely achieved. Atribut performance management ditargetkan menjadi Largely Achieved atau Full Achieved sedangkan saat ini masih Not achieved dan atribut work product management ditargetkan Largely Achieved atau Full Achieved sedangkan saat ini masih Partially achieved.

Keempat pada proses manage continuity (DSS04) atribut proses performance ditargetkan menjadi Full Achieved sedangkan saat ini masih bernilai Not achieved. Atribut performance management ditargetkan menjadi Largely Achieved atau Full Achieved sedangkan saat ini masih Not achieved dan atribut work product management ditargetkan Largely Achieved atau Full Achieved sedangkan saat ini masih Partially achieved.

Kelima pada proses manage security service (DSS05) atribut proses performance ditargetkan menjadi Full Achieved sedangkan saat ini masih bernilai Largely achieved. Atribut performance management ditargetkan menjadi Largely Achieved atau Full Achieved sedangkan saat ini masih Partially achieved dan atribut work product management ditargetkan Largely Achieved atau Full Achieved sedangkan saat ini masih Not achieved.

Keenam pada proses manage process businiss (DSS06) atribut proses performance ditargetkan menjadi Full Achieved sedangkan saat ini masih bernilai Partially achieved. Atribut performance management ditargetkan menjadi Largely Achieved atau Full Achieved sedangkan saat ini masih Not achieved dan atribut work product management ditargetkan Largely 
Achieved atau Full Achieved sedangkan saat ini masih Not achieved.

Berdasarkan nilai yang ditunjukkan pada analisa level kapabilitas saat ini dan level kapabilitas yang diharapkan atau target pada Sistem Informasi Diskominfo Kota Payakumbuh maka diperoleh temuan penelitian terlihat bahwa terdapat kelemahan dalam tata kelola dan manajemen TI pada Dinas Komunikasi dan Informatika Kota Payakumbuh. Proses pengelolaan $\mathrm{TI}$ terutama dalam domain pelaksanaan belum terlaksana dengan baik. Beberapa proses belum melaksanakan praktek-praktek dasar untuk proses tersebut. Tidak dilaksanakannya praktekpraktek dasar akan berakibat tidak tercapainya proses tersebut. Proses yang praktek dasarnya belum terlaksana dengan baik adalah pengelolaan permintaan layanan dan gangguan (DSS02), pengelolaan berkesinambungan (DSS04) dan pengelolaan proses bisnis (DSS06).

Tidak terlaksananya praktek dasar pada pengelolaan permintaan layanan dan gangguan akan berakibat pada penurunan produktifitas, meningkatnya kasus gangguan dan tidak tertanganinya permintaan layanan dan gangguan secara cepat. Hal ini yang menyebabkan pelayanan berbasis $\mathrm{TI}$ tidak berjalan dengan baik, sering terjadi gangguan layanan tidak tertangani dengan cepat sehingga menyebabkan pelayanan terhenti sama sekali dan implementasi TI tidak memberikan kontribusi positif pada layanan justru berdampak negatif terhadap kinerja pelayanan (Nugroho \& Fahmi, 2015).

Pembagian peran dan tanggung jawab merupakan hal yang mutlak ada dalam tata kelola dan manajemen, demikian juga halnya dalam tata kelola dan manajemen $\mathrm{TI}$ (Andono et al., 2017; Putri, 2016). Tata kelola $\mathrm{TI}$ adalah kumpulan proses yang saling terkait dan terstrukturisasi untuk mengarahkan dan mengontrol organisasi dalam mencapai tujuan (Prawira \& Darmizal, 2016; Purwanto et al., 2017). Tata kelola TI mendistribusikan peran, tugas dan tanggung jawab struktural organisasi (seperti dewan direksi, manajemen eksekutif), memberikan pertimbangan dan prosedur untuk membuat keputusan terkait TI. Pelaksanaan tata kelola berdasarkan strukturisasi seperangkat tujuan $\mathrm{TI}$, dan bagaimana mencapai tujuan tersebut beserta monitoring (Ariyadi, 2014; Susanto, 2014).

Penelitian ini didukung oleh penelitian sebelumnya yang relevan, seperti: (1) penelitian yang dilaksanakan oleh (Kurniawan, 2018), yang mendapatkan hasil yaitu Dinas Kependudukan dan Catatan Sipil Kabupaten Bogor telah memiliki pola untuk mengelola proses terkait berdasarkan keberhasilan pengalaman yang berulang yang pernah dilakukan sebelumnya tetapi pola yang dilakukan belum berstandar. (2) penelitian yang dilaksanakan oleh (Fajarwati et al., 2018), yang mendapatkan hasil yaitu implementasi TI di Kantor Kecamatan Baturraden telah berjalan dan mencapai tujuannya, namun belum ada proses untuk memastikan keuntungan dalam proses pengiriman dan optimasi resiko yang ditetapkan, dan dicapai keluaran yang sesuai harapan. (3) penelitian yang dilaksanakan oleh (Rizki et al., 2016), yang mendapatkan hasil yaitu evaluasi pengukuran kualitas sistem, kualitas informasi dan kualitas layanan BI di PMRI berdasarkan tingkat kepentingan dan kinerja bisa disimpulkan bahwa untuk kualitas sistem kinerja yang rendah dan perlu mendapat prioritas utama untuk perbaikannya yaitu keandalan sistem BI, aksesibilitas, serta efisiensi. Sedangkan untuk peningkatan kualitas informasi dapat memperioritaskan atribut akurasi dan tepat waktu.

Berdasarkan beberapa penelitian yang relevan tersebut, adapun kebaruan penelitian ini adalah belum ada yang melaksanakan penelitian tentang evaluasi tata kelola teknologi informasi di dinas komunikasi dan informatika menggunakan framework cobit 5, khususnya pada pada organisasi pemerintahan. Dari defenisi diatas dapat disimpulkan bahwa salah satu komponen penting dari tata kelola TI adalah adanya distribusi peran dan tanggung jawab struktural organisasi. Peran dan tanggung jawab struktural organisasi dalam COBIT 5 dijabarkan dalam tabel RACl yang terdiri dari siapa saja yang bertanggung jawab terhadap aktivitas maupun proses tetentu (Responsible) mengetahui dan menyetujui 
aktivitas sebelum dijalankan (Accountable), memberikan konsultasi dan input atas

\section{SIMPULAN}

Dari hasil evaluasi terhadap tata kelola teknologi informasi pada Dinas Komunikasi dan Informatika Kota Payakumbuh dapat diambil simpulan bahwa kondisi tata kelola teknologi informasi Dinas Komunikasi dan Informatika Kota Payakumbuh saat ini sebagian aktivitas pengelolaan TI telah terlaksana tapi sebagian lagi masih belum terlaksana, penilaian tingkat kapabilitas proses menunjukkan hasil dari 6 proses yang diukur dapat diketahui bahwa baru ada 3 proses yaitu proses pengelolaan operational, pengelolaan masalah dan pengelolaan keamanan layanan yang dapat mencapai level 1 (performed process) dengan kategori atribut process performance mencapai Largely Achieved. Sedangkan 3 proses yang lain yaitu proses pengelolaan permintaan layanan dan gangguan, pengelolaan keberlanjutan layanan dan pengelolaan proses bisnis masih berada pada level 0 (Incomplete Process), tingkat kapabilitas proses yang menjadi target atau harapan dari pihak manajemen Dinas Kominfo Kota Payakumbuh adalah level 2 (Managed Process) dan dapat dicapai dengan menjalankan rekomendasi yang telah diberikan.

\section{DAFTAR PUSTAKA}

Andono, B., Suroso, A. I., \& Purnaningsih, N. (2017). Tata Kelola Sistem Informasi pada Perusahaan Pelayaran Lepas Pantai. Jurnal Aplikasi Bisnis Dan Manajemen, 3(2), 313-323. https://doi.org/10.17358/jabm.3.2.313

Ariyadi, D. (2014). Evaluasi Tingkat Kematangan Proses Pengelolaan Data Pada Sistem Informasi E-Learning SMKN 1 Jenangan Menggunakan Cobit Quickstart. Multitek Indonesia, 8(1), 36-54.

Damayanti, R., \& Manuputty, A. D. (2019). Analysis of Information Technology Governance In Department of Communication and Informatics of Salatiga Using COBIT 5 Framework. aktivitas (Consulted), diinformasikan mengenai aktivitas dan hasil (Informed).

Journal of Information Systems and Informatics, 1(2), 97-122. https://doi.org/10.33557/journalisi.v1i2. 12

Fajarwati, S., Sarmini, S., \& Septiana, Y. (2018). Evaluasi Tata Kelola Teknologi Informasi Menggunakan Kerangka Kerja COBIT 5. JUITA: Jurnal Informatika, 6(2), 73. https://doi.org/10.30595/juita.v6i2.2019

Firdaus, N. Z., \& Suprapto. (2018). Evaluasi Manajemen Risiko Teknologi Informasi Menggunakan COBIT 5 IT Risk (Studi Kasus : PT . Petrokimia Gresik). Jurnal Pengembangan Teknologi Informasi Dan Ilmu Komputer, 2(1), 91-100. https://doi.org/10.21460/jutei.2018.12.5 3

Hariyani, D. S., \& Sudrajat, M. A. (2017). Analisis Pengaruh Kompetensi Aparatur Pemerintahan Desa Terhadap Penggunaan Teknologi Accounting Information System Pada Desa-Desa Di Kabupaten Madiun. Assets: Jurnal Akuntansi Dan Pendidikan, 5(2), 113. https://doi.org/10.25273/jap.v5i2.1193

Ismail, M. P., \& Winarno, W. W. (2017). Manajemen Sumber Daya Teknologi Informasi Laboratorium Komputer Menggunakan Balanced Scorecard (BSC) dan COBIT 5. Jurnal Infotel, 9(2), 158.

https://doi.org/10.20895/infotel.v9i2.16 9

Kurniawan, D. T. (2018). Evaluasi Tata Kelola Teknologi Informasi E-Ktp Menggunakan Framework Cobit (Studi Kasus: Dinas Kependudukan Dan Catatan Sipil Kabupaten Bogor). Jurnal Penelitian Pos Dan Informatika, 8(2), 123.

https://doi.org/10.17933/jppi.2018.0802 03

Mutiah, N. (2019). Penilaian Tata Kelola Teknologi Informasi Universitas Tanjungpura Menggunakan Cobit 5 Domain Align, Plan, Dan Organise 
(APO). Computer Engineering, Science and System Journal, 4(1), 65. https://doi.org/10.24114/cess.v4i1.114 57

Najwa, N. F., \& Susanto, T. D. (2018). Kajian dan Peluang Penelitian Tata Kelola Teknologi Informasi: Ulasan Literatur. Jurnal Teknologi Informasi Dan IImu Komputer, $\quad 5(5), \quad 517$. https://doi.org/10.25126/jtiik.20185582 7

Nugroho \& Fahmi, A. (2015). Analisis Tingkat Kapabilitas Sistem Informasi Rumah Sakit Berdasarkan Cobit 5 ( Mea01 ) Pada Rsud. Techno.COM, 14(4), 291-298.

Prawira, M. K., \& Darmizal, T. (2016). Perencanaan Strategis Teknologi Informasi Dinas Pendapatan Daerah Kabupaten Rokan Hilir Menggunakan Framework Ward and Peppard. 2(1), 813.

Purwanto, L., Informatika, T. D.-J. J., \& 2018, undefined. (2017). Pengukuran Tingkat Kematangan Tata Kelola Pengelolaan Permasalahan Sistem Informasi Menggunakan Kerangka Kerja COBIT 4.1 (Studi Kasus: Sistem Informasi. Jurnalnasional.Ump.Ac.ld,

V(November), 103-113. http://jurnalnasional.ump.ac.id/index.ph p/JUITA/article/view/1629
Putri, R. E. (2016). Penilaian Kapabilitas Proses Tata Kelola TI Berdasarkan Proses DSS01 Pada Framework COBIT 5. Jurnal CorelT, 2(1), 41-54.

Rizki, Y. A., Suroso, A. I., \& Ramadhan, A. (2016). Evaluasi Tata Kelola Sistem Informasi Business Intelligence pada Perusahaan Minuman Ringan. Jurnal Manajemen Teknologi, 15(3), 279-296. https://doi.org/10.12695/jmt.2016.15.3. 5

Suradi, A., \& Wiyanta, S. (2017). Framework Cobit Untuk Identifikasi Tingkat Kematangan Tata Kelola Teknologi Informasi: Studi. Khazanah Informatika: Jurnal IImu Komputer Dan Informatika, 3(1), 38-42.

Susanto, A. (2014). Analisis Kebutuhab Tata Kelola Teknologi Informasi Pada Implementasu Program Universal Service Obligation. Penelitian Pos Dan Informatika, 4(2), 87-167.

Utomo, M., Holil, A., Ali, N., \& Affandi, I. (2012). Pembuatan Tata Kelola Keamanan Informasi Kontrol Akses Berbasis ISO/IEC 27001:2005 Pada Kantor Pelayanan Perbendaharaan Surabaya I. Jurnal Teknik Its, 1(1), 2-7. http://ejurnal.its.ac.id/index.php/teknik/ article/viewFile/900/462 